\section{Haveria base normativa para restringir as receitas da previdência social às contribuições previdenciárias?}

\author{
WOULD IT BE NORMATIVE BASIS TO RESTRICT THE \\ SOCIAL SECURITY INCOMES ONLY TO SOCIAL \\ SECURITY CONTRIBUTIONS?
}

* Mauro da Motta Aguiar

Resumo: Manifestações a respeito da “difícil” situação da Previdência Social adotam como tese subjacente que o custeio do RGPS dever-se-ia restringir às receitas oriundas das contribuições sobre a folha de salários. Daí surgiu, então, o questionamento de até que ponto seria efetivamente viável identificar-se, no direito positivo brasileiro vigente, quais, dentre as receitas previstas para o financiamento da Seguridade Social, poderiam ser entendidas como destináveis à Previdência Social, inquirição essa que constituiu o objetivo deste trabalho. O exame da matéria iniciou-se pelo texto da Lei Maior. As acusações que se fazem quanto ao teor generoso da Constituição Cidadã conduziram a que também se pesquisasse a situação nos normativos legais expedidos no período precedente. Após tal busca regressiva, analisou-se o tratamento da matéria no principal instrumento infraconstitucional a ela dedicado, a saber, a Lei 8.212/1991. O estudo findou por demonstrar a inviabilidade de identificar-se suporte, a partir da leitura direta do texto constitucional ou daquele das leis que dispõem sobre o tema, para a tese que pretende restringir, entre as receitas da Seguridade Social, o leque daquelas que podem ser utilizadas pela Previdência Social.

Palavras-chave: Regime Geral de Previdência Social. Fontes de financiamento. Exame da possibilidade de restrições normativas.

Abstract: Speeches about the social security “difficult” situation usually adopt as underlying thesis that RGPS funding should be restricted to the revenues from contributions on the payroll. From there came the question of how far would effectively be identifiable, on the brazilian current positive law, wich, among the revenues prescripted to support the Welfare System, could be considered as addressable to Social Security, inquiry wich was the objective of this work. The examination of the subject was initiated by the text of the Higher Law. The charges that are 
made regarding the "Citizen Constitution" generous content also led to research the situation in legal regulations issued in the previous period. After such a reverse search, the subject treatment was analyzed in the main infraconstitutional instrument about the theme, namely, the 8.212/1991 act. The research ended by showing the impossibility of identifying up support, from the direct reading of the Constitution or the laws that we have on the topic, for the thesis that wants to restrict, among the welfare incomes, the range of those than can be used by Social Security.

Keywords: Social Security General System. Sources of funding. Possibility of normative constraints examination. 


\section{INTRODUÇÃO}

Com certa frequência, as manifestações a respeito da “difícil” situação da previdência social fazem questão de estabelecer nítida separação entre esta e o restante da seguridade social, geralmente com a intenção de justificar o aspecto de seus argumentos a respeito de "déficit” restringirem as receitas do RGPS à denominada "arrecadação líquida”, correspondente à diferença entre os "Recebimentos Próprios” e as "Transferências a Terceiros”, com que o sistema deveria, a seu ver, contar para dar conta de seus encargos. ${ }^{1}$ Tal argumentação é veiculada ao ponto de ser frequente ouvir-se, em resposta ao argumento de que haveria outras fontes a serem consideradas para o custeio da previdência social, que essas se destinariam aos outros segmentos da seguridade.

A existência de tais alegações levanta a questão de até que ponto seria efetivamente viável identificar-se, de acordo com o direito positivo brasileiro atual, quais, dentre as receitas previstas para o custeio da Seguridade Social, quais as que poderiam ser entendidas como destináveis à Previdência Social. Esse, então, o questionamento que o presente artigo se propôs a buscar responder, a partir do exame das disposições constitucionais e legais a respeito do tema.

O exame da matéria foi iniciado pelo texto da Lei Maior, já que, a princípio, é daí que deve decorrer todo o restante do direito positivo vigente. No entanto, as frequentes acusações que se fazem ao teor generoso da Constituição Cidadã conduziram a que também se pesquisasse como seria a situação, no que se refere à previsão da forma de financiamento da Previdência Social, nos normativos expedidos no período precedente. Por fim, após tal busca regressiva, promoveu-se o exame do tratamento da matéria no instrumento infraconstitucional a ela dedicado, a saber, a Lei 8.212/1991.

A intenção da pesquisa foi, então, de perquirir até que ponto haveria suporte, nas disposições normativas a respeito do tema, para as teses de que a

\footnotetext{
Essa, ademais, é tendência reforçada pelo próprio Ministério da Previdência Social, que faz questão de divulgar, no demonstrativo referente ao Fluxo de Caixa do INSS, os verbetes "Saldo Previdenciário (Arrec. Líquida - Benef. Previd.)" e "Saldo Arrecadação Líquida - Total de Benefícios Pagos" (BRASIL, Ministério da Previdência Social, 2013, p. 716-721). Quanto a alguns exemplos de manifestações no sentido referido, vide, no que se refere àqueles que dedicaram obras inteiras ao tema ou ao menos artigos de densidade razoável, GIAMBIAGI (2007) e BERZOINI (2003, p. 1925). No que se refere a falas constantes de matérias jornalísticas mais rápidas, vide, igualmente para citar apenas alguns poucos exemplos, "Previdência tem déficit 165,9\% maior em março", "Governo discute opção '95/105' ao fator previdenciário" e "Fim do fator previdenciário aumentará déficit do INSS", publicadas, no Jornal Estado de São Paulo, nas datas de, respectivamente, 2/5/ 2013, 20/2/2013 21/11/2012.
} 
Previdência Social deva sustentar-se apenas com as contribuições sobre a folha de salários.

\section{A CONSTITUIÇÃO FEDERAL DE 1988 E AS DISPOSIÇÕES A RESPEITO DAS RECEITAS E DESPESAS DA SEGURIDADE SOCIAL E DA PREVIDÊNCIA SOCIAL}

Topograficamente inseridas no Título relativo à Ordem Social, as disposições a respeito da Previdência Social integram o Capítulo II daquela divisão do texto constitucional, capítulo esse dedicado à Seguridade Social. Esta última, por sua vez, é definida, pelo art. 194, como conjunto de ações destinadas a assegurar os direitos relativos à saúde, à previdência e à assistência social. A previsão do conceito de seguridade social constituiu inovação da Constituição de 1988 (BRASIL, 1988) e correspondeu a resposta a objetivo ansiado por diversos dos doutrinadores acerca do tema, para quem o conceito de seguridade social é identificado como um degrau mais “evoluído” do que aquele da previdência social, ${ }^{2}$ constituindo, ademais, ressonância da vertente que aqui anteriormente se identificou com a predominância da caridade.

O problema, necessário ressaltar, não se relaciona tanto com a distinção em tese entre as diferentes áreas integrantes da seguridade social, consoante disposições da Constituição Federal de 1988. Nesse sentido, do próprio texto da Lei Maior podem ser extraídas “pistas”. Nos termos do art. 196, a saúde, direito de todos (universal) e dever do Estado, deverá ser garantida mediante políticas sociais e econômicas de caráter preventivo ou que viabilizem o acesso às ações e serviços dirigidos para sua promoção, proteção e recuperação.

Já segundo o art. 201, a previdência social, a ser organizada sob a forma de regime geral, será de caráter contributivo e de filiação obrigatória, devendo observar-se o seu equilíbrio financeiro e atuarial, e se destinará a atender a cobertura de eventos de doença, invalidez, morte e idade avançada (inc. I); a proteção à maternidade (inc. II); a proteção ao desemprego involuntário (inc. III); ao salário-família e ao auxílio-reclusão (inc. IV); à pensão por morte (inc. V); à aposentadoria por tempo de contribuição (§ $7^{\circ}$, inc. I) ou por idade (§ $7^{\circ}$, inc. II).

2 Vide, por exemplo, Horvath Júnior (2004, p. 31), Balera (2004, p. 56) e Leite (1992, p. 17). Importante a ressalva, no entanto, de o atributo de "mais evoluído" nem sempre ser empregado expressamente por esses autores. Considera-se, contudo, mesmo aí ser possível concluir nesse sentido, tendo em vista a forma como a passagem de uma forma para a outra é apresentada. 
Por fim, de acordo com o art. 203, assegura-se que a assistência social será prestada a quem dela necessitar, independentemente de contribuição à seguridade social, explicitando-se que referida área objetivará a proteção à família, à maternidade, à infância, à adolescência e à velhice (inc. I); o amparo às crianças e adolescentes carentes (inc. II); a integração ao mercado de trabalho (inc. III); a habilitação e reabilitação de portadores de deficiência, assim como sua integração à vida comunitária (inc. IV); a garantia de um salário mínimo de benefício mensal ao portador de deficiência e ao idoso que comprovem não possuir meios para prover sua manutenção ou de tê-la provida por sua família (inc. V).

Além dessas sinalizações oriundas do próprio texto constitucional, a doutrina cuida de apresentar várias propostas para a distinção entre os três segmentos em questão. Para Leite (1978, p. 20), a "previdência social” praticamente retomaria o significado de seguro social, já que custeada por prestações individuais diretas dos segurados, complementadas por contribuições simultâneas das empresas e do Estado, enquanto isso, a "assistência social” abrangeria benefícios que, como regra, prescindiriam de contribuições dos beneficiários.

Interessante visão sobre a matéria é apresentada por Balera (2004, p. 72-75), para quem a seguridade social, consoante definida no texto constitucional vigente, contará com duas vias de ação: a previdenciária, que explicita como correspondente ao seguro social, e a assistencial, que abrangeria tanto o sistema de saúde quanto o de assistência social. Ou, em outras palavras, que a seguridade social seria o gênero, do qual a previdência, a saúde e a assistência social constituiriam espécies.

Quanto a isso, verifica-se que o texto Constitucional vigente dedica, à Seguridade Social, todo um Capítulo do Título Correspondente à Ordem Social. ${ }^{3}$ Referido capítulo, por sua vez, conta com quatro seções, sendo a primeira atinente a disposições gerais, enquanto as outras três são dedicadas, respectivamente, à Saúde, à Previdência Social e à Assistência Social.

Não bastasse a disposição topográfica, ainda se deve considerar, para reforçar a tese gênero-espécie, a disposição do caput do art. 194 da CF/1988, já anteriormente mencionado, no sentido de que a seguridade social compreenderia conjunto integrado de ações de iniciativa dos Poderes Públicos e da sociedade, “destinadas a assegurar os direitos relativos à saúde, à previdência e à assistência social”.

${ }^{3}$ Capítulo esse que abrange 11 artigos, do 194 ao 204. 
Além disso, também há elementos para referendar a tese das duas vias de ação da seguridade social, a via previdenciária e a via assistencial. Ao dispor sobre a previdência social, o caput do art. 201 dispõe que ela deva ser "de caráter contributivo" e de que, em sua organização, sejam observados critérios que preservem seu “equilíbrio financeiro e atuarial”, regras essas estreitamente vinculadas aos sistemas de seguro social. Por sua vez, a confirmar o caráter assistencial dos dois outros braços da seguridade, encontram-se as disposições dos arts. 196 e 203.

Nesse sentido, o art. 196 estabelece ser a saúde "direito de todos e dever do Estado", assegurando-se o "acesso universal e igualitário às ações e serviços para sua promoção”. Por sua vez, o art. 203 explicita que a assistência social será prestada a quem dela necessitar, "independentemente de contribuição à seguridade social”. Em ambos os casos, portanto, constata-se que o acesso ao serviço, ainda que sujeito à condição da necessidade no caso da assistência social, independerá de qualquer contribuição, prévia, concomitante ou posterior. O caráter assistencial, portanto, resta devidamente configurado.

Ademais, retornando à questão quanto à possibilidade de identificar-se, a partir do texto da Lei Maior, a distinção entre os três segmentos da seguridade social, se aceito como tendo alguma validade o brocardo hermenêutico verba cum effectu, sunt accipienda (em tradução literal, "devem-se compreender as palavras como tendo alguma eficácia”, ou, em sua forma mais conhecida "não se presumem, na lei, palavras inúteis"), ${ }^{4}$ poder-se-ia inferir que a seguridade social abrange três áreas que, ao menos em algum grau, poderiam e deveriam ser distinguidas. A partir do texto da Carta Magna, no entanto, essa segregação nem sempre é tão nítida ou fácil.

Verifica-se, aliás, todo um esforço por parte do legislador constitucional em tratar de forma unificada a seguridade social, não só pelo fato de haver optado por reunir sob sua abrangência três áreas tão amplas, mas também ao decidir estabelecer-lhes diretivas de forma unificada. Quanto a isso, verifica-se que o parágrafo único do art. 194 da CF/1988 estabeleceu a obrigação de que o legislador ordinário, ao tratar da organização da seguridade social, o fizesse com base nos seguintes objetivos:

a) universalidade da cobertura e do atendimento;

b) uniformidade e equivalência dos benefícios e serviços às populações urbanas e rurais;

${ }^{4}$ Para uma boa explanação acerca dos brocardos hermenêuticos, assim como uma discussão a respeito de sua validade, vide Maximiliano (2009, p. 195-240). O brocardo aqui enfocado é abordado no $\S 307$. p. 204. 
c) seletividade e distributividade na prestação dos benefícios e serviços;

d) irredutibilidade do valor dos benefícios;

e) equidade na forma de participação no custeio;

f) diversidade da base de financiamento;

g) caráter democrático e descentralizado da administração, mediante gestão quadripartite, com participação dos trabalhadores, dos empregadores, dos aposentados e do Governo nos órgãos colegiados.

O relacionamento de cada um desses objetivos com todas as três áreas integrantes da seguridade social, no entanto, nem sempre parece tão claro. Ao menos a partir de uma interpretação mais literal e rasa, é difícil conceber, por exemplo, que se possa vincular a diretriz de irredutibilidade do valor dos benefícios com a esfera da saúde, já que aquela área, no que tange à seguridade social, não lida com benefícios, mas com ações e serviços. ${ }^{5}$ Sob o mesmo prisma, igualmente não é tranquila a aceitação do estabelecimento de vínculo entre a diretiva de equidade na forma de participação no custeio e a assistência social, tendo em vista tratar-se de segmento em que se assegura a prestação independentemente de contribuição. ${ }^{6}$

Justamente na direção oposta, aliás, alguns desses objetivos parecem destinados a dirigir a atuação apenas em um ou dois dos "braços” da seguridade social, tal como, por exemplo, no que se refere à universalidade de cobertura e de atendimento, cuja estreita vinculação com a saúde parece mostrar-se mais evidente. A previsão de uniformidade e equivalência dos benefícios e serviços às populações urbanas e rurais, por sua vez, soa como associada, primordialmente, com as áreas da previdência e da assistência, embora, registre-se, pareça relacionada mais de perto com a primeira dessas.

Importante ressaltar, no entanto, que não se está, com essas palavras, pretendendo defender que não seria possível, a partir de um maior esforço de interpretação, estabelecer a vinculação entre referidos objetivos e as três áreas integrantes da Seguridade Social. Em sentido diverso, aliás, é possível verificar que diversos doutrinadores apresentam suas respostas para a questão. As visões variam, contudo, desde um extremo onde há autores que se limitam a analisar detalhadamente cada um desses objetivos e relacioná-los genericamente com toda a Seguridade Social ${ }^{7}$ até na outra ponta, onde há aqueles que, com base em cuidadosa compreensão dos componentes de cada vertente da Seguridade

\footnotetext{
5 Vide arts. 197 e 198, caput, da CF/1988.

${ }^{6}$ Conforme caput do art. 203 da CF/1988.

7 Tal como é o caso, por exemplo, de Balera (2004, p. 81-95).
} 
Social, procuram identificar quais princípios se aplicariam a cada uma delas. ${ }^{8}$ Ainda é possível individualizar posições, que poderiam ser classificadas como intermediárias, daqueles que desenvolvem esforços para maximizar a percepção, em relação todos os objetivos constitucionalmente previstos, quanto a quais de seus aspectos diriam respeito a cada uma das vertentes da Seguridade Social. ${ }^{9}$

O que aqui se defende é que, ao que indica a disposição constante do art. 194 da Constituição Federal, a intenção do legislador constituinte foi de, como parte da elaboração de um novo capítulo em relação à proteção social no Brasil, defender que a Seguridade Social seja tratada como um todo, um conjunto. Nesse sentido, entende-se que, qualquer que seja a corrente entre aquelas referidas logo acima que venha a adotar, o intérprete se verá sempre forçado a ter em conta todo o quadro da Seguridade Social. Além disso, outro fator sinaliza a ausência de intenção de que os objetivos em questão fossem divididos de forma estanque entre os diferentes segmentos da seguridade social, a saber, o aspecto de que, quando se pretendeu estabelecer diretrizes específicas para cada um deles, tais dispositivos foram inseridos na respectiva seção.

Por certo que há quem aponte, contudo, que o capítulo constitucional atinente à seguridade social corresponderia a uma tentativa incompleta de evolução. Nesse sentido, em relato elaborado pouco após a Constituinte de 1987-1988, Teixeira (1991, p. 1-2) apresenta, como justificativa inicial para a caminhada que conduziu à introdução do conceito de seguridade social na Constituição Cidadã, um lugar comum em relação ao capitalismo brasileiro, qual seja, o fato de ser dinâmico o suficiente para tornar-se a oitava economia do mundo capitalista, mas incapaz de sanar uma série de problemas, o mais grave deles sendo o da miséria absoluta. ${ }^{10}$

Encurtando significativamente, então, sua narrativa histórica, da qual constou menção à transição, do sistema previdenciário brasileiro, do regime de capitalização para o de repartição simples e ao recorrente descumprimento, por parte da União, de contribuir para o custeio do sistema, nos termos da legislação então vigente, referido autor descreve que a inclusão do capítulo da seguridade social no corpo da Constituição seria fruto de uma coalizão de um grupo de técnicos e intelectuais reunidos no Ministério da Previdência e Assistência Social, durante as gestões dos ministros Waldir Pires, Raphael de Almeida Magalhães e Renato Archer, com o movimento dos médicos sanitaristas (TEIXEIRA, 1991, p. 16, 19-20 e 28).

8 Tal como, por exemplo, Vianna (2010, p. 15-19).

9 Vide, a título de exemplo, Martins (2013, p. 54-62).

${ }^{10}$ Oportuno o destaque de que a elaboração de tal obra data de dezembro de 1990. 
Relata que as propostas da mencionada coalizão findaram por influenciar fortemente o Congresso Constituinte e, em particular, as comissões de Ordem Social e de Sistematização. Isso, contudo, haver-se-ia verificado "sem uma discussão aprofundada de todos os aspectos conceituais, operacionais e financeiros da proposta”. De tal quadro, haveriam resultado, a seu ver, por um lado, o caráter híbrido que o modelo assumiu (de manter a aposentadoria por tempo de serviço e em falhas de definição quanto ao financiamento da seguridade) e, por outro, com a dissolução do grupo técnico e a consequente perda da memória dos fundamentos teóricos do conceito de seguridade, a pouca tendência do Congresso em defender os "avanços” que a proteção social no Brasil havia obtido com a nova Carta (TEIXEIRA, 1991, p. 26-29).

Importante ressaltar, no entanto, a posição por ele também defendida, de que, com as conquistas obtidas com a seguridade social, confirmou-se a "tendência inequívoca do sistema brasileiro de proteção social a se afirmar como um sistema redistributivo e assistencial, e não apenas como mero seguro" (TEIXEIRA, 1991, p. 26). Dentro da nomenclatura que aqui se decidiu adotar, seria a preponderância da vertente da caridade.

Se a promoção, a partir do texto constitucional, da segregação que os arautos da situação crítica da previdência social pretendem que se promova já não é tão simples no que se refere ao aspecto mais conceitual, objetivo similar torna-se ainda mais difícil, quanto a intentar-se, como o faz referida corrente, de destacar quais, dentre as receitas da seguridade, seriam as fontes de receita que se deveria direcionar exclusivamente a cada um de seus segmentos.

Quanto a isso, verifica-se que a redação original da Constituição Federal de 1988, ainda na Seção I, relativa às disposições gerais a respeito da seguridade social, estabeleceu, em seu art. 195, que aquela política pública seria financiada por toda a sociedade, de forma direta e indireta, "mediante recursos provenientes dos orçamentos da União, dos Estados, do Distrito Federal e dos Municípios, e das seguintes contribuições sociais":

a) dos empreendedores, incidente sobre a folha de salários, o faturamento e o lucro;

b) dos trabalhadores;

c) sobre a receita de concursos de prognósticos.

Observe-se que, claramente, o legislador constituinte não fez questão alguma, no referido dispositivo, de segregar quais, dentre referidas receitas, deveriam destinar-se a cada uma das áreas integrantes da Seguridade Social, optando, justamente em sentido diverso, por atribuí-las ao custeio de toda a 
área. Não bastasse tal disposição de caráter geral, pode-se constatar que, nos regramentos específicos da saúde e de assistência social, há a referência expressa de que serão promovidas com as receitas do art. $195 .^{11}$ Em outras palavras, seria possível, até mesmo, que os outros dois segmentos da seguridade viessem a ser supridos com os denominados "recebimentos próprios" (contribuição dos empregadores sobre a folha salarial + contribuições dos trabalhadores) da previdência social, ainda que diante da nítida constatação de que, historicamente, tais receitas sejam vinculadas à esfera do seguro social. ${ }^{12}$

Digno de nota, também, o aspecto de todas as bases de incidência de contribuições sociais dos empreendedores (a folha de salários, o faturamento e o lucro) serem tratadas no mesmo inciso. ${ }^{13}$ Essa situação, ademais, perdurou até a promulgação da Emenda Constitucional 20/1998 (BRASIL, 1998), por intermédio da qual, além do estabelecimento de limitações às aposentadorias dos servidores públicos e outras medidas, sendo uma delas uma explicitação mais ampla das categorias de empregadores, cuidou-se de dividir o inc. I do art. 195 em três alíneas. Na oportunidade, instituiu-se, também, a possibilidade de contribuições sociais sobre os importadores de bens ou serviços, ou daqueles a eles equiparados.

Na nova configuração, então, as possíveis contribuições sociais de onde poderia provir o custeio da seguridade social passaram a ser previstas como sendo as seguintes:

a) do empreendedor, da empresa e da entidade a ela equiparada na forma da lei, incidentes sobre:

a.1) a folha de salários e demais rendimentos do trabalho pagos ou creditados, a qualquer título, à pessoa física que lhe preste serviço, mesmo sem vínculo empregatício;

a.2) a receita ou o faturamento;

a.3) o lucro;

\footnotetext{
${ }^{11}$ Nesse sentido, vide, no que se refere à saúde, o $\S 1^{\circ}$ do art. 198, e, no que tange à assistência social, o caput do art. 204, todos da CF/1988. Ou seja, até mesmo as receitas sobre as quais seria difícil haver polêmica quanto a seu "caráter previdenciário", as contribuições de empregadores e empregados, poderiam ser direcionadas para os outros segmentos da seguridade social, como de fato já foram, conforme reconhecido por Giambiagi (1996, p. 15-17 e 19).

${ }^{12}$ Essa última condição, ademais, findou por verificar-se em mais de um exercício, consoante ressaltado por Giambiagi (1996, p. 15-17), ao lamentar a praticamente cessação, a partir de 1993, do “cheque", atinente à diferença entre as receitas de "contribuições previdenciárias" e o pagamento de benefícios previdenciários, que era repassado para custear despesas da Saúde.

${ }^{13}$ No caso, o inc. I do art. 195 da CF/1988.
} 
b) do trabalhador e dos demais segurados da previdência social, não incidindo contribuição sobre aposentadoria e pensão concedidas pelo regime geral de previdência social de que trata o art. 201;

c) sobre a receita de concursos de prognósticos;

d) do importador de bens ou serviços do exterior, ou de quem a lei a ele equiparar.

Somente do texto em questão, no entanto, ainda não se logra identificar qualquer referência restritiva ou, no linguajar orçamentário, qualquer previsão de especialização de receitas entre os "braços” da Seguridade Social. Ao mesmo tempo, no entanto, também não se entende viável identificar com certeza qual foi a intenção do Poder Executivo com a divisão em alíneas do inc. I do art. 195, já que a justificativa para tanto não constou da Mensagem 306/1995, embora se possa apontar a tentativa de aperfeiçoamento da redação original, com vistas a afastar eventual confusão entre custeio da relação de trabalho (folha de salários) e custeio do empreendimento (receita ou faturamento e lucro) (BRASIL, Congresso Nacional, 1995). ${ }^{14}$

O único indicativo constitucional expresso de especialização de receita, oriundo, ademais, da aprovação de substitutivo à PEC 33/1995, é favorável à Previdência Social (BRASIL, Congresso Nacional, 1996). Trata-se, no caso, da vedação constante do inc. XI do art. 167, no sentido de que as receitas das contribuições previstas no art. 195, I, a, e II, atinentes às contribuições dos empregadores sobre a folha de salários (art. 195, I, a) e às contribuições dos trabalhadores (art. 195, II), somente possam ser empregadas para o pagamento de benefícios do RGPS. Pode-se interpretar, assim, que, por meio da Emenda Constitucional 20/1998 (oriunda da PEC 33/1995), corrigiu-se falha redacional que possibilitava empregos questionáveis de receitas que, historicamente, sempre foram vinculadas ao seguro social, cujos beneficiários são exclusivos.

Ou seja, conforme registra Ibrahim (2012, p. 123-125), os únicos casos em que se pode falar em exclusividade de destinação, no que se refere às contribuições da Seguridade Social, dizem respeito justamente às contribuições previdenciárias (art. 195, I, “a”, e II da Constituição Federal de 1988), vinculadas unicamente à Previdência Social, por força do inc. XI do art. 167 da CF/1988.

\footnotetext{
${ }^{14}$ Registre-se que a divisão do inc. I em três alíneas já constava da Proposta de Emenda Constitucional encaminhada pelo Poder Executivo (PEC 33/1995), embora ela ainda não contemplasse a vedação de incidência de contribuições sociais sobre as aposentadorias e pensões do RGPS. Aliás, a proposta original igualmente não contemplava incidência de contribuições sobre os importadores. Posteriormente referida PEC veio a ser desmembrada, dando origem, no que se tange à matéria de interesse deste trabalho, à PEC 33-A/1995.
} 
Tal vinculação, a propósito, seria estabelecida com clareza suficiente para excluílas da Desvinculação de Receitas da União - DRU, assim como para não permitir sua inibição pelo fato de sua arrecadação e fiscalização também serem promovidas pela Secretaria de Receita Federal do Brasil. Todas as demais podem ser destinadas a qualquer dos segmentos da Seguridade Social, aí também incluída a Previdência Social.

Verifica-se, no entanto, que a vedação mencionada é que constitui o fundamento alegado para que as receitas oriundas da relação de trabalho, denominadas “contribuições previdenciárias”, devessem ser a única fonte de receita com que deveria contar a Previdência Social para suportar suas obrigações. Considera-se, no entanto, à luz do texto constitucional vigente, não ser possível que se possa concluir, apenas em função da existência de contribuições exclusivas, que essas deveriam constituir as únicas fontes destinadas a suportar o custeio da Previdência Social. ${ }^{15}$ Aliás, as disposições constitucionais pertinentes permitem a conclusão, significativamente distinta, de que se pode afirmar que todas as receitas da Seguridade Social também o são da Previdência Social, mas não o contrário.

Oportuno, por se estar abordando as disposições do art. 195, recuperarse, uma vez mais, o registro de Anísio Teixeira acerca das motivações para referida configuração. A diversificação da base de financiamento, em especial com o estabelecimento de contribuições que teriam por base o faturamento ou lucro, era vista como solução, não para ampliar-se o volume de recursos disponíveis, mas para reduzir-se a vulnerabilidade das receitas previdenciárias às flutuações do ciclo econômico (TEIXEIRA, 1991, p. 27-28). Possível a interpretação, portanto, de que, ao contrário do que muitas vezes se defende, o rol ampliado de receitas foi cogitado, originariamente, apenas para a previdência social, findando por ser posteriormente direcionado, também, para o atendimento dos demais segmentos da seguridade social.

\section{PRECEDENTES DA DIVERSIDADE DE FONTES DE CUSTEIO}

Os indicativos, ademais, são de que a preocupação com a existência de receitas outras, além das contribuições dos empregados e empregadores, já vem de mais tempo atrás. Nesse sentido, verifica-se que, desde a sua redação original, a denominada Lei Orgânica da Previdência Social (LOPS), Lei 3.807

${ }^{15}$ Conforme, aliás, sustenta Pierdoná (2007, p. 29). 
de 26/8/1960 (BRASIL,1960), já previa, como uma das fontes de receita da área, a contribuição, por parte da União, “em quantia igual ao total das contribuições de que trata a alínea $a$ [correspondente à contribuição dos segurados] destinada a custear o pagamento do pessoal e as despesas de administração geral das instituições de previdência social”, além de prever-se que aquele ente público seria responsável por cobrir eventuais insuficiências financeiras e déficits. ${ }^{16}$

Referido dispositivo, aliás, não constitui inovação absoluta da LOPS, verificando-se que já havia regra similar, no sentido de que a União devesse comparecer com montante idêntico ao do total de contribuição dos segurados, no $\S 1^{\circ}$ do art. 54 do Regulamento Geral dos Institutos de Aposentadorias e Pensões, aprovado pelo Decreto 35.448, de $1^{\circ}$ de maio de 1954 (BRASIL,1954), embora, à época, ainda não fosse agregada a tal disposição a previsão genérica de responsabilidade do ente público federal pela cobertura de eventuais insuficiências e déficits.

A previsão expressa de contribuição do Estado para o custeio previdenciário, aliás, também não constituía inovação do regulamento geral dos institutos, já havendo sido prevista, ainda que sob roupagens um pouco diferentes, nos regramentos de cada uma daquelas instituições.

Assim, no que se refere ao primeiro dos Institutos de Aposentadorias e Pensões, o dos Marítimos, restou estabelecido, por meio da alínea “c” do art. 11 e os arts. 12, 13 e 14 do Decreto 22.872, de 29 de junho de 1933 (BRASIL,1933), que o Estado contribuiria com uma "quota de previdência”, cujo funding proviria da cobrança de taxa sobre os serviços prestados pelas categorias abrangidas por aquele instrumento. ${ }^{17}$ Em acréscimo, nos termos do art. 14 do referido decreto, caso, em verificação a ser promovida anualmente, a arrecadação da quota de previdência fosse inferior ao montante da contribuição dos associados, o Governo Federal deveria responder perante o instituto pela diferença e, enquanto não a honrasse, deveria pagar-lhe juros, à taxa anual de $6 \%$, sobre o montante de tal obrigação.

Disposição similar constou da alínea "c" do art. $4^{\circ}$ e dos arts. $5^{\circ}$ e $6^{\circ}$ do Decreto 24.273, de 22 de maio de 1934 (BRASIL, 1934a), ${ }^{18}$ que cuidou de

\footnotetext{
${ }^{16}$ Vide alínea $d$ do art. 69 da Lei 3.807, de 26/8/1960.

${ }^{17}$ Segundo o art. $2^{\circ}$ do Decreto 22.872, de 29/6/1933, suas disposições abrangeriam os serviços de "navegação marítima, fluvial e lacustre, a cargo da União, dos Estados, Municípios e particulares nacionais, bem como os da indústria da pesca”.

${ }^{18}$ Cabe o registro de a menção a tal instrumento encontrar-se incorreta no site do Ministério da Previdência Social, lá constando a indicação do Decreto 24.272.
} 
criar o Instituto de Aposentadoria e Pensões dos Comerciários. Igualmente nesse caso, o Estado deveria contribuir com o produto da arrecadação da "quota de previdência", esta oriunda de "sêlo especial" aposto sobre "contas, faturas, recibos, ou duplicatas, e outros documentos de quitação das vendas mercantis". Nessa hipótese, contudo, não houve o estabelecimento de vinculação entre o montante arrecadado para a "quota” e a contribuição dos segurados.

Disposição praticamente idêntica a essa última constou, também, da alínea “c" do art. $3^{\circ}$ e dos arts. $4^{\circ}$ e $5^{\circ}$ do Decreto 24.615, de 9 de julho de 1934 (BRASIL, 1934b), que criou o Instituto de Aposentadoria e Pensões dos Bancários. A diferença ficou por conta, apenas, da proveniência da quota da previdência, no caso incidente sobre "os juros pagos ou creditados pelos bancos e casas bancárias, nas respectivas contas de depósitos, a toda e qualquer pessoa física ou jurídica”.

Ao dispor sobre a criação e o funcionamento do Instituto de Aposentadoria e Pensões dos Industriários, a Lei 367, de 31/12/1936 (BRASIL,1936), estatuiu, no inc. I de seu art. $4^{\circ}$, que contribuiriam, em montantes idênticos, tanto os empregadores, quanto os empregados e a União. A contribuição desta última deveria provir da denominada "taxa de previdência social”, instituída pelo art. $6^{\circ}$ da Lei 159, de 30/12/1935 (BRASIL,1935), correspondente à cobrança de $2 \%$ sobre os pagamentos de artigos importados, excetuados, apenas, o combustível e o trigo. No caso, contudo, de tais recursos serem insuficientes para atingir o montante a cargo do ente público federal, este deveria arcar com a importância restante, mediante a devida previsão de tal responsabilidade em seu orçamento anual.

Ao criar, mediante transformação da anterior Caixa de Aposentadoria e Pensões dos Trabalhadores em Trapiches e Armazéns, o Instituto de Aposentadoria e Pensões dos Empregados em Transportes e Cargas, o Decreto-Lei 651, de 26/8/1938 (BRASIL, 1938), estabeleceu, no item 4 de seu art. $4^{\circ}$, a obrigatoriedade de contribuição, por parte da União, encargo esse que proviria da cobrança de uma taxa sobre as utilidades recolhidas ou depositadas em trapiche ou armazém ou despachadas sobre água e de outra aplicada sobre litro de carburante entregue ao consumo. De acordo com o § $3^{\circ}$ do referido art. $4^{\circ}$, no entanto, se a arrecadação das duas taxas mencionadas, em apuração anual, superasse o total de contribuições dos segurados, o excesso seria depositado na conta especial do Ministério do Trabalho, Indústria e Comércio prevista no caput do art. 11 da Lei 159, de 30/12/1935 (BRASIL, 1935). 
Dispondo sobre o agrupamento de todas as Caixas de Aposentadoria e Pensões então existentes em uma única instituição, denominada Caixa de Aposentadoria e Pensões dos Ferroviários e Empregados em Serviços Públicos, o Decreto 34.586, de 12/11/1953 (BRASIL, 1953), não chegou a dispor sobre as fontes de receita da instituição criada, constando, do art. 17 daquele instrumento, que ela seria regulada pela legislação aplicável às entidades a serem fundidas.

A identificação regressiva de disposições nesse sentido, aliás, poderia prosseguir perscrutando os diversos regramentos atinentes às anteriores Caixas de Aposentadorias e Pensões. Considera-se, no entanto, que o retorno até o momento da aparição dos Institutos já se mostra suficiente para demonstrar a preocupação com o estabelecimento de receitas adicionais para amparar a política em questão, no meio das quais sempre se encontrava previsão acerca da responsabilidade do Governo Federal.

A fim de que não se pense que não haveria disposições similares no período anterior, pode-se mencionar que a própria Lei Elói Chaves ${ }^{19}$ já contava, na alínea "c" de seu art. $3^{\circ}$, com previsão de fonte de receita que, ainda que não se refira expressamente ao Estado, possuía tal caráter, já que proveniente da cobrança da taxa de 1,5\% sobre as tarifas da estrada de ferro. Com caráter semelhante, eram também definidas como possíveis fontes de receita, no mesmo artigo, os valores pagos a maior pelo público e não reclamados no prazo de um ano (alínea $f$ ) e as multas que atingissem o público ou seu pessoal (alínea $g$ ).

\section{O UNIVERSO DO PLANO DE CUSTEIO DA SEGURIDADE SOCIAL - PCSS (LEI 8.212/1991)}

Retornando ao universo pós-Constituição de 1988, é possível verificar que nem mesmo a Lei 8.212, de 24 de julho de 1991 (BRASIL, 1991), denominada de Lei Orgânica da Seguridade Social ou, mais comumente, Plano de Custeio da Seguridade Social - PCSS, possibilita a clara segregação entre quais das fontes de receita deveriam ser associadas unicamente a um de seus "braços”, a ponto de suportar a tese dos segmentos que pretendem restringir as fontes de custeio da Previdência Social. Justamente em sentido distinto e, ao mesmo tempo, afinado com o texto constitucional, dispõe o PCSS, em seu art. 10, que a Seguridade Social será financiada por toda a sociedade, de forma direta e

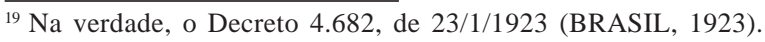


indireta, "mediante recursos provenientes da União, dos Estados, do Distrito Federal, dos Municípios e de contribuições sociais”.

Logo em seguida, prossegue o PCSS (BRASIL, 1991), em seu art. 11, estabelecendo que o orçamento da Seguridade Social seria composto, quanto ao seu custeio, por (a) receitas da União, (b) receitas das contribuições sociais e (c) receitas de outras fontes, rol cujo caráter extremamente genérico, ademais, além de não possibilitar eventual segregação entre as áreas da seguridade, nem mesmo permite identificar que fontes de recursos estariam aí compreendidas as denominações utilizadas, ademais, possibilitam a inclusão de quase qualquer coisa.

Disposição um pouco mais precisa consta do parágrafo único do referido art. 11, no sentido de estabelecer quais contribuições corresponderiam ao qualificativo de "sociais”, estabelecendo rol que, apesar de taxativo, comporta abertura em cada um dos itens, em função de serem todos iniciados por artigo definido plural. Assim, nos termos daquele dispositivo, constituiriam contribuições sociais:

a) as das empresas, incidentes sobre a remuneração paga ou creditada aos segurados a seu serviço;

b) as dos empregados domésticos;

c) as dos trabalhadores, incidentes sobre o seu salário-de-contribuição;

d) as das empresas, incidentes sobre faturamento e lucro;

e) as incidentes sobre a receita de concursos de prognósticos.

No que se refere às contribuições sociais, a propósito, entendimento manifestado pelo Supremo Tribunal Federal, quando do julgamento das Ações Diretas de Inconstitucionalidade 2.556 e 2.568, defendeu ser possível a distinção entre contribuições sociais "gerais” e “da seguridade social”. A partir daí, é possível, então, a conclusão de poderem ser consideradas como seguramente vinculadas à Seguridade Social apenas as contribuições sociais previstas no art. 195 da CF/1988, abrindo-se o caminho para que outras exações da espécie criadas a partir do disposto no art. 149 da Carta Magna possam a ela ser direcionadas ou atribuídas a outros segmentos sociais alheios à sua esfera (IBRAHIM, 2012, p. 124).

No que tange às contribuições da seguridade social, no entanto, tampouco no universo do PCSS surgem indicativos diversos daqueles constantes do texto constitucional, permanecendo sem suporte, com base no instrumento legal que depõe sobre a matéria, as teses que pretendem apontar quais, dentre tais receitas, não poderiam ser atribuídas à Previdência Social. 


\section{CONSIDERAÇÕES FINAIS}

O que se constata, portanto, é a inviabilidade de identificar-se suporte, a partir da leitura direta do texto constitucional ou daquele das leis que dispõem sobre o tema, para a tese que pretende restringir, entre as receitas da Seguridade Social, o leque daquelas que podem ser utilizadas pela Previdência Social. Além disso, é possível verificar que, ainda no período anterior ao da Lei Maior ora vigente, já havia disposições a respeito da vinculação de outras receitas à previdência social, isso mesmo antes de falar-se no conceito mais abrangente de Seguridade Social. Ou seja, nem mesmo o ordenamento jurídico anterior fornece subsídios para que se conclua de onde proviriam os entendimentos a respeito de pretender-se limitar os recursos da Previdência Social apenas àqueles oriundos da relação de trabalho.

Acerca do tema, uma vez mais, considera-se oportuno reiterar o aspecto de que, se alguma das três áreas da Seguridade Social conta com recursos exclusivos, essa área é a da Previdência Social. Tal situação restou clara após a mudança de redação inserida no inc. XI do art. 167 da Constituição Federal por força da Emenda Constitucional 20/1998. Mesmo antes de tal alteração redacional, no entanto, todos os precedentes históricos, ao menos no que se refere aos observados no Brasil, já permitiriam concluir pela vinculação das receitas oriundas da relação de trabalho com a Previdência Social. Além disso, conforme também já dito anteriormente, não há suporte para afirmar que essas seriam as únicas receitas da Previdência Social, seja antes da EC 20/1998, seja após.

Há indicativos, ademais, de que a linha de argumentação seja alimentada pela denominação, atribuída às contribuições previstas no art. 195, I, a, e II, da Constituição Federal de 1988, de “contribuições previdenciárias”. Ou seja, um mecanismo de proteção inserido por força da EC 20/1998, no inc. XI do art. 167 do texto constitucional, segundo o qual as contribuições dos empregadores sobre a folha de salários (art.195, I, a) e as contribuições dos trabalhadores somente poderão ser empregadas para o pagamento de benefícios do RGPS, finda por ser utilizado com propósito diverso, a saber, de sustentar o argumento de que elas corresponderiam às únicas fontes da Previdência Social. Contudo, conforme já reiteradamente manifestado neste estudo, não há fundamentos, no quadro jurídico-normativo vigente, que suportem tal tese. 


\section{REFERÊNCIAS}

BALERA, Wagner. Noções preliminares de direito previdenciário. São Paulo: Quartier Latin, 2004. p. 222.

BERZOINI, Ricardo. Previdência social: a mudança com justiça e respeito. In: MORHY, Lauro (org.). Reforma da previdência em questão. Brasília: Editora Universidade de Brasília, 2003. p. 19-25.

BRASIL. Congresso Nacional. Proposta de Emenda à Constituição n. 33/1995. Modifica o sistema de previdência social, estabelece normas de transição e dá outras providências. Diário do Congresso Nacional de 11/4/ 1995, Seção I, p. 6038-6044. Disponível em http://imagem.camara.gov.br/ Imagem/d/pdf/DCD11ABR1995.pdf, acesso em 20/11/2013.

BRASIL. Congresso Nacional. Substitutivo à Proposta de Emenda à Constituição n. 33/1995. Diário da Câmara dos Deputados de 23/4/1996, p. 10673-10682. Disponível em http://imagem.camara.gov.br/Imagem/d/pdf/ DCD23ABR1996.pdf\#page=250, acesso em 20/3/2014.

BRASIL. Constituição da República Federativa do Brasil de 1988. Disponível, quanto a seu texto original, em http://www.senado.gov.br/ legislacao/con1988/CON1988_05.10.1988/index.shtm, acesso em 28/1/2014, e, quanto a seu texto atualizado, em http://www.planalto.gov.br/ccivil_03/ constituicao/constituicao.htm, acesso em 20/1/2014.

BRASIL. Decreto n. 22.872, de 29 de junho de 1933. Crêa o Instituto de Aposentadoria e Pensões dos Maritimos, regula o seu funcionamento e dá outras providencias. Disponível em http:/www3.dataprev.gov.br/SISLEX/ paginas/23/1933/22872.htm, acesso em 11/12/2013.

BRASIL. Decreto n. 24.273, de 22 de maio de 1934. Cria o Instituto de Aposentadoria e Pensões dos Comerciários, dispõe sobre o seu funcionamento e dá outras providências. Disponível em http:// legis.senado.gov.br/legislacao/ListaPublicacoes.action?id=30922\& tipoDocumento=DEC\&tipoTexto=PUB, acesso em 20/11/2013. 
BRASIL. Decreto n. 24.615, de 9 de julho de 1934. Cria o Instituto de Aposentadoria e Pensões dos Bancários. Disponível em http:// legis.senado.gov.br/legislacao/ListaPublicacoes.action?id=38285\& tipoDocumento=DEC\&tipoTexto=PUB, acesso em 20/11/2013.

BRASIL. Decreto n. 34.586, de 12 de novembro de 1954. Determina a fusão de Caixas de Aposentadorias e Pensões e dá outras providências. Disponível em http://www2.camara.leg.br/legin/fed/decret/1950-1959/ decreto-34586-12-novembro-1953-328044-publicacaooriginal-1-pe.html, acesso em 13/12/2013.

BRASIL. Decreto n. 35.448 de $\mathbf{1}^{\circ}$ de maio de 1954. Expede o Regulamento Geral dos Institutos de Aposentadoria e Pensões. Disponível em http://www2.camara.leg.br/legin/fed/decret/1950-1959/decreto-35448-1maio-1954-327399-publicacaooriginal-1-pe.html, acesso em 20/11/2013.

\section{BRASIL. Decreto Legislativo n. 4.682, de 24 de janeiro de 1923.} Crea, em cada uma das emprezas de estradas de ferro existentes no paiz, uma caixa de aposentadoria e pensões para os respectivos empregados. Disponível em http://www.planalto.gov.br/ccivil_03/decreto/Historicos/DPL/ DPL4682.htm, acesso em 22/12/2013.

BRASIL. Decreto-Lei n. 651, de 26 de agosto de 1938. Altera a organização da Caixa de Aposentadoria e Pensões dos Trabalhadores em Trapiches e Armazens e dá outras providências. Disponível em http:// legis.senado.gov/legislacao/ListaPublicacoes.action?id=102072\& tipoDocumento=DEL\&tipoTexto=PUB, acesso em 11/12/2013.

BRASIL. Emenda Constitucional n. 20, de 15 de dezembro de 1998. Modifica o sistema de previdência social, estabelece normas de transição e dá outras providências. Disponível em http://www2.camara.leg.br/legin/fed/ emecon/1998/emendaconstitucional-20-15-dezembro-1998-356870normaatualizada-pl.html, acesso em 20/1/2014.

BRASIL. Lei n. 159, de 30 de dezembro de 1935. Regula a contribuição para a formação da receita dos Institutos e Caixas de Aposentadoria e Pensões subordinados ao Conselho do Trabalho e dá outras providências. 
Disponível em http://www2.camara.leg.br/legin/fed/lei/1930-1939/lei-159-30dezembro-1935-499861-publicacaooriginal-1-pl.html, acesso em 10/12/2013.

BRASIL. Lei n. 367, de 31 de dezembro de 1936. Crêa o Instituto de Aposentadoria e Pensões dos Industriarios Subordinados ao Ministerio do Trabalho, Industria e Comércio, e dá outras providências. Disponível em http://www2.camara.leg.br/legin/fed/lei/1930-1939/lei-367-31-dezembro1936-555119-publicacaooriginal-73230.pl.html, acesso em 21/11/2013.

BRASIL. Lei n. 3.807, de 26 de agosto de 1960. Dispõe sôbre a Lei Orgânica da Previdência Social. Disponível, quanto à sua forma original, em http://legis.senado.gov.br/legislacao/ListaPublicacoes.action?id=113037 \&tipoDocumento=LEI\&tipoTexto=PUB, acesso em 12/5/2014, e, quanto à sua forma atualizada, em http://www3.dataprev.gov.br/sislex/paginas/42/ 1960/3807.htm, acesso em 23/1/2014.

BRASIL. Lei n. 8.212, de 24 de julho de 1991. Dispõe sobre a organização da Seguridade Social, institui Plano de Custeio, e dá outras providências. Disponível, quanto a seu texto original, em http:// www2.camara.leg.br/legin/fed/lei/1991/lei-8212-24-julho-1991-363647publicacaooriginal-1-pl.html, acesso em 28/12/2013, e, quanto a seu texto atualizado, em http://www.planalto.gov.br/ccivil_03/leis/18212cons.htm, acesso em 28/12/2013.

BRASIL. Ministério da Previdência Social. Anuário estatístico da previdência social 2012. Brasília: MPS/Dataprev, 2013. p. 889.

GIAMBIAGI, Fabio. A crise fiscal da União: o que aconteceu recentemente? Rio de Janeiro: BNDES, 1996 (Texto para discussão, n. 35). p. 21.

GIAMBIAGI, Fabio. Reforma da previdência: o encontro marcado - a difícil escolha entre nossos pais ou nossos filhos. 2. ed. Rio de Janeiro: Elsevier, 2007. p. 227.

HORVATH JÚNIOR, Miguel. Direito previdenciário. 4. ed. São Paulo: Quartier Latin, 2004. p. 415. 
IBRAHIM, Fábio Zambitte. Curso de direito previdenciário. 17. ed. Rio de Janeiro: Impetus, 2012. p. 911.

LEITE, Celso Barroso. A proteção social no Brasil. 2. ed. São Paulo: LTr, 1978. p. 126.

LEITE, Celso Barroso. Conceito de seguridade social. In: BALERA, Wagner (Organizador). Curso de direito previdenciário: Homenagem a Moacyr Velloso Cardoso de Oliveira. São Paulo: LTr, 1992. p. 13-32.

MARTINS, Sergio Pinto. Direito da seguridade social. 33. ed. São Paulo: Atlas, 2013. p. 561.

MAXIMILIANO, Carlos. Hermenêutica e aplicação do direito. Rio de Janeiro: Forense, 2009. 19. ed. p. 342.

PIERDONÁ, Zélia Luiza. A proteção social na constituição de 1988.

Revista de direito social. n. 28. v. 7. out/dez 2007. Porto Alegre: Notadez, 2007. p. 11-29.

TEIXEIRA, Aloísio. Do seguro à seguridade: a metamorfose incompleta do sistema previdenciário brasileiro. Rio de Janeiro: UFRJ/ IEI, 1991. p. 44.

VIANNA, João Ernesto Aragonés. Curso de direito previdenciário. 3. ed. São Paulo: Atlas, 2010. p. 687.

Artigo recebido em: 09/11/2014 Aprovado para publicação em: 19/08/2015

Como citar: AGUIAR, Mauro da Motta. Haveria base normativa para restringir as receitas da previdência social às contribuições previdenciárias? Revista do Direito Público. Londrina, v.10, n.2, p.145-165, mai./ago. 2015. DOI: 10.5433/1980-511X.2015v10n2p145. 